\title{
DAYA DUKUNG LINGKUNGAN DAN KELEMBAGAAN USAHA KERAMBA JARING APUNG (KJA) DI WADUK JATILUHUR
}

\author{
Nurmala Fitri ${ }^{{ }^{*}}$, Aceng Hidayat ${ }^{1}$, Prima Gandhi ${ }^{1}$ \\ ${ }^{1}$ Departemen Ekonomi Sumberdaya dan Lingkungan, Fakultas Ekonomi dan Manajemen \\ Institut Pertanian Bogor (IPB), Bogor 16680 \\ *Email: nurmala.fitri2012@gmail.com
}

\begin{abstract}
RINGKASAN
Waduk Jatiluhur menjadi penyedia air baku, pengairan lahan pertanian (irigasi), Pembangkit Listrik Tenaga Air (PLTA), pengendali banjir bagian hilir waduk, tempat wisata dan budidaya perikanan khususnya budidaya ikan Keramba Jaring Apung (KJA). Manfaat ekonomi yang dirasakan masyarakat dari keberadaan KJA antara lain adalah peningkatan pendapatan dan taraf hidup, perluasan kesempatan kerja, dan terpenuhinya kebutuhan konsumsi sumber protein ikan. Manfaat ekonomi yang dihasilkan KJA mendorong masyarakat untuk terus membangun KJA, sayangnya aktivitas KJA di Waduk Jatiluhur belum memperhatikan aspek daya dukung perairan sehingga terjadi penurunan kualitas air waduk. Perhitungan daya dukung Waduk Jatiluhur perlu dilakukan sebagai langkah awal dalam memperkirakan jumlah KJA maksimum agar dampak negatif dari aktivitas KJA dapat dihindari. Penelitian ini bertujuan untuk: (1) menganalisis daya dukung Waduk Jatiluhur, (2) menganalisis kelembagaan, dan (3) menganalisis persepsi stakeholder yang terlibat dalam pengelolaan KJA di Waduk Jatiluhur. Jumlah unit KJA intensif di Waduk Jatiluhur berdasarkan Laporan Tahunan Perum Jasa Tirta II tahun 2014 sebanyak 23.000 KJA. Berdasarkan hasil perhitungan dengan metode Beveridge dalam penelitian ini jumlah KJA sudah berlebih. Jumlah KJA optimal di Waduk Jatiluhur adalah 19.401 petak KJA. Pengelolaan Waduk Jatiluhur terkait KJA dilakukan oleh beberapa pihak dengan persepsi berbeda. Persepsi berbeda dapat mempengaruhi pengambilan keputusan atau pencapaian tujuan dari pengelolaan Waduk Jatiluhur terkait KJA. Maka, diperlukan identifikasi persepsi dari semua pihak agar meningkatkan produktivitas KJA dan mempertahankan atau memperbaiki kualitas lingkungan.
\end{abstract}

Kata kunci: kelembagaan, keramba jaring apung (KJA), keberlanjutan, daya dukung

\section{PERNYATAAN KUNCI}

- Undang-Undang Republik Indonesia Nomor 45 Tahun 2009 tentang Perikanan bahwa perairan umum seperti sungai, danau, waduk, rawa, dan genangan air lainnya yang berada dalam kedaulatan Republik Indonesia dapat diusahakan sebagai lahan pembudidayaan ikan dengan tetap memperhatikan daya dukung dan kelestariannya untuk dimanfaatkan sebesarbesarnya bagi kesejahteraan dan kemakmuran rakyat Indonesia. 
- Kegiatan budidaya KJA merupakan usaha perikanan air tawar yang dapat dikembangkan secara intensif, dengan luas perairan yang terbatas dan pemberian pakan buatan, maka budidaya KJA berpotensi untuk dikembangkan dalam skala industri. Faktor input yang mudah diakses menjadi salah satu alasan masyarakat terus mengembangkan usaha KJA, sehingga jumlah KJA yang ada telah melebihi daya dukung ekologi waduk. Padahal dalam pengembangan usaha KJA harus tetap memperhatikan kualitas dan kelestarian perairan waduk untuk keberlanjutan usaha KJA. Pengembangan usaha KJA ditentukan oleh unsur cemaran dari sisa pakan yang masuk ke perairan, seperti fosfor $\left(\mathrm{PO}_{4}\right)$ dan nitrogen $\left(\mathrm{NH}_{3}, \quad \mathrm{NO}_{2}, \quad \mathrm{NO}_{3}\right)$ karena dapat memicu terjadinya proses eutrofikasi. Kemudian, apabila terjadi proses pembalikan massa air (upwelling) di wilayah perairan waduk maka akan menyebabkan kematian massal pada ikan budidaya KJA.

- Penghitungan daya dukung waduk dilakukan untuk memperkirakan jumlah produksi ikan maksimum dan jumlah petak KJA optimum yang sesuai dengan kemampuan waduk. Analisis kelembagaan KJA Waduk Jatiluhur melihat substansi kelembagaan yaitu peraturan formal yang berkaitan dengan KJA Waduk Jatiluhur. Analisis persepsi dari masing-masing stakeholderyang terlibat dalam pengelolaan KJA Waduk Jatiluhur dilakukan melalui aspek ekologi, ekonomi, dan pengelolaan. Jumlah unit KJA intensif di Waduk Jatiluhur berdasarkan Laporan Tahunan Perum Jasa Tirta II tahun 2014 sebanyak 23.000 KJA. Berdasarkan hasil perhitungan dengan metode Beveridge dalam penelitian ini jumlah KJA sudah berlebih. Jumlah KJA optimal di Waduk
Jatiluhur adalah 19.401 petak KJA.

\section{REKOMENDASI KEBIJAKAN}

- Perlu dilakukannya pengurangan dan atau pembatasan jumlah petakan KJA di Waduk Jatiluhur agar meminimalkan tingkat pencemaran perairan akibat kandungan pospat. Langkah yang dapat ditempuh oleh stakeholders untuk meningkatkan daya dukung Waduk Jatiluhur terhadap aktivitas budidaya ikan dengan sistem KJA salah satunya adalah dengan mengurangi jumlah pakan yang diberikan, menghindari penggunaan bahanbahan yang berpotensi mencemari lingkungan, atau dengan menurunkan kepadatan atau laju sedimentasi di wilayah perairan Waduk Jatiluhur.

- Rekomendasi Struktur Tata Kelola Waduk Jatiluhur dan Perikanan.

- Secara eksisting, Perum Jasa Tirta II (PJTII) tidak memiliki hubungan langsung dengan penyuluh perikanan. Hal ini dikarenakan kegiatan perikanan merupakan kegiatan usaha tambahan yang memanfaatkan wilayah perairan waduk sehingga PJTII kurang memfokuskan diri pada kegiatan usaha perikanan. Padahal, kegiatan perikanan berpotensi memberikan dampak negatif terhadap wilayah perairan Waduk Jatiluhur, seperti sisa pakan dan sisa metabolisme dari ikan. Selain itu, adanya sampah buangan dari penjaga KJA juga ikut menurunkan kualitas air. Oleh karena itu, jika hubungan PJTII dan penyuluh perikanan serta hubungan PJTII dengan kelompok pelaku usaha perikanan menjadi hubungan yang konsultatif, maka interaksi antar stakeholder ini akan membantu meningkatkan kesadaran pelaku usaha 


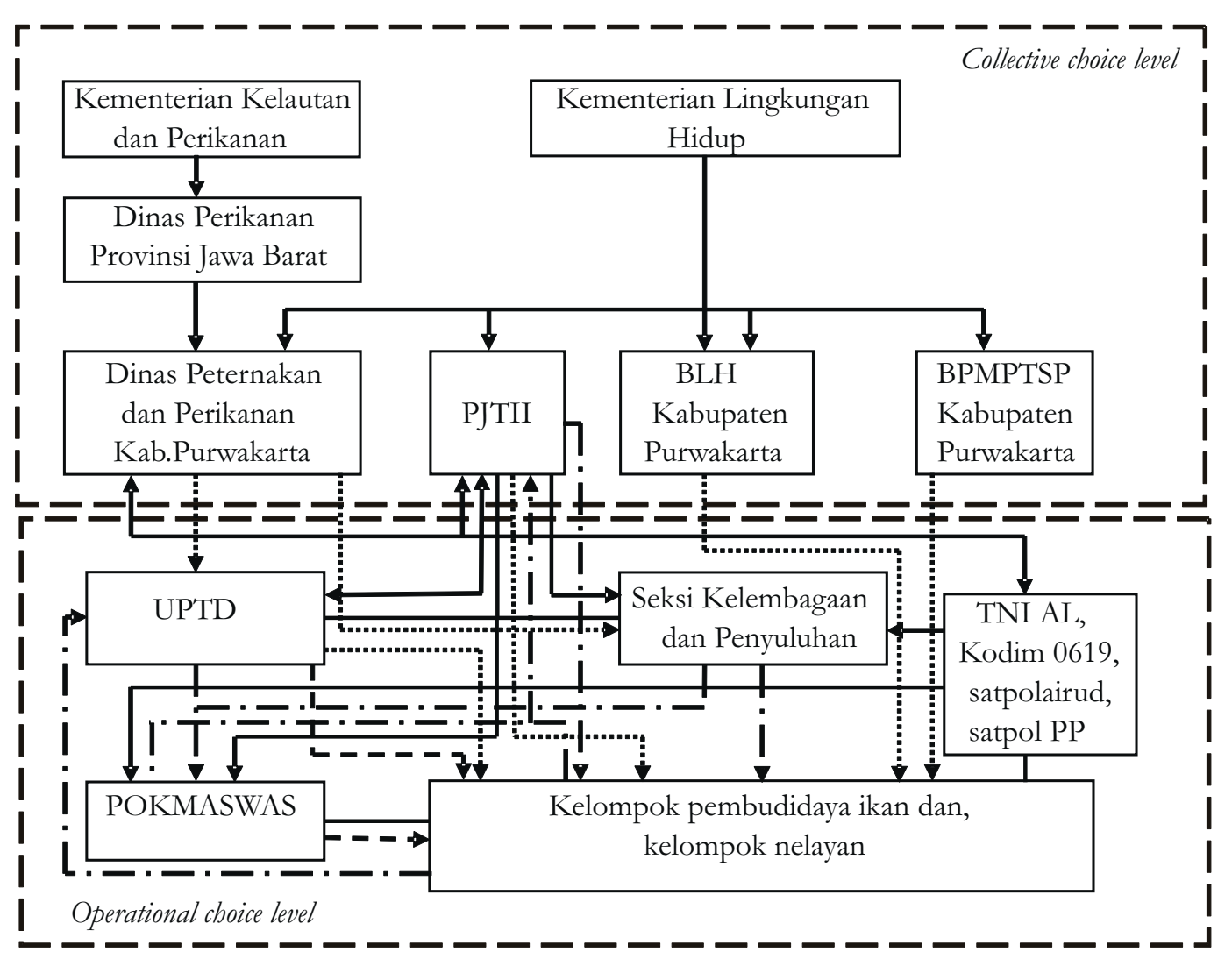

Gambar 1 Rekomendasi struktur tata kelola waduk dan perikanan

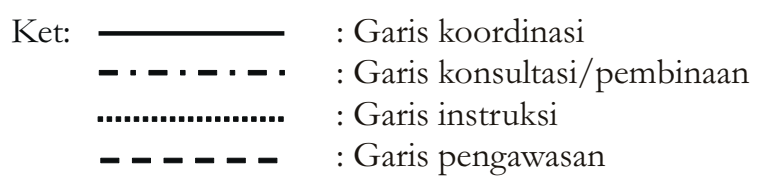

perikanan terhadap kelestarian wilayah perairan waduk dan menjadi langkah awal dalam upaya penjagaan kualitas wilayah perairan waduk. Maka dari itu, peran PJTII terkait pengelolaan usaha perikanan sangat diperlukan agar kegiatan usaha perikanan dapat terkoordinasi dengan baik dan tidak memberikan dampak negatif terhadap lingkungan Waduk Jatiluhur.

\section{PENDAHULUAN}

Bendungan Jatiluhur merupakan bendungan terbesar di Indonesia yang membendung aliran sungai Citarum di Kecamatan Jatiluhur,
Kabupaten Purwakarta, Provinsi Jawa Barat. Bendungan Jatiluhur membentuk waduk dengan genangan seluas lebih kurang $( \pm) 83 \mathrm{~km}^{2}$ dan keliling waduk $150 \mathrm{~km}^{2}$ pada elevasi muka air normal $\pm 107 \mathrm{~m}$ di atas permukaan laut (dpl). Luas daerah tangkapan Bendungan Jatiluhur sebesar $4.500 \mathrm{~km}^{2}$, sedangkan luas daerah tangkapan yang langsung ke waduk setelah dibangun Bendungan Saguling dan Bendungan Cirata di hulunya menjadi tinggal $380 \mathrm{~km}^{2}$. Angka ini merupakan $8 \%$ dari keseluruhan daerah tangkapan bendungan. Daerah tangkapan (upper Citarum) meliputi wilayah Kabupaten Bandung, Kabupaten Bandung Barat, Kota Bandung, Kota Cimahi, Kabupaten Cianjur, dan Kabupaten Purwakarta.

Bendungan Jatiluhur dirancang untuk memiliki 
kapasitas tampungan sebesar 3 milyar $\mathrm{m}^{3}$, namun saat ini hanya tinggal 2,44 milyar $\mathrm{m}^{3}$ (hasil pengukuran batimetri tahun 2000) akibat adanya sedimentasi. Lebih jauh, Bendungan Jatiluhur merupakan bendungan multiguna, yaitu: (a) sebagai pembangkit listrik dengan kapasitas terpasang 187,5 MW, (b) sebagai pengendali banjir di Kabupaten Karawang dan Bekasi, (c) sebagai sumber pengairan irigasi untuk lahan seluas 242.000 ha, (d) sebagai pemasok air untuk kebutuhan rumah tangga dan industri, (e) sebagai pemasok air untuk kegiatan budidaya perikanan air dan (f) sebagai lokasi wisata.

Manfaat ekonomi yang dihasilkan KJA mendorong masyarakat untuk terus membangun dan mengembangkan KJA. Pengembangan usaha KJA ditentukan oleh unsur cemaran dari sisa pakan yang masuk ke perairan, seperti fosfor $\left(\mathrm{PO}_{4}\right)$ dan nitrogen $\left(\mathrm{NH}_{3}, \mathrm{NO}_{2}, \mathrm{NO}_{3}\right)$ karena dapat memicu terjadinya proses eutrofikasi. Kemudian, apabila terjadi proses pembalikan massa air (upwelling) di wilayah perairan waduk maka akan menyebabkan kematian massal pada ikan budidaya KJA. Aktivitas KJA di Waduk Jatiluhur belum memerhatikan aspek daya dukung perairan sehingga terjadi penurunan kualitas air waduk.

Pelaksanaan budidaya perikanan perlu memperhatikan kaidah-kaidah ekologis agar dampak negatif dari aktivitas budidaya perikanan dapat dihindari. Perhitungan daya dukung lingkungan waduk dapat dilakukan sebagai langkah awal untuk mengetahui kemampuan waduk tersebut dalam mendukung sejumlah biomas ikan, sehingga dapat dilakukan estimasi mengenai jumlah unit KJA maksimum yang sesuai dengan daya dukung waduk. Oleh karena itu, perhitungan daya dukung Waduk Jatiluhur perlu dilakukan sebagai langkah awal dalam pengestimasian jumlah KJA maksimum agar dampak negatif dari aktivitas KJA dapat dihindari.

Kelembagaan yang ada di Waduk Jatiluhur tidak hanya terbatas pada pengelolaan waduk tetapi juga pengelolaan aktivitas budidaya KJA. Kelembagaan yang baik dapat membatasi jumlah KJA dengan memberikan perizinan usaha KJA yang berdasarkan aturan perundang-undangan yang berlaku dan melihat daya dukung (carrying capacity) ekologi waduk.

Pengelolaan Waduk Jatiluhur terkait KJA dilakukan oleh beberapa pihak yang masingmasing dari pihak tersebut memiliki persepsi yang berbeda. Persepsi yang berbeda dapat mempengaruhi pengambilan keputusan atau pencapaian tujuan dari pengelolaan Waduk Jatiluhur terkait KJA. Maka, diperlukan identifikasi persepsi dari semua pihak agar dapat meningkatkan produktivitas KJA dan mempertahankan atau memperbaiki kualitas lingkungan waduk.

\section{SITUASI TERKINI}

Salah satu manfaat Waduk Jatiluhur bagi masyarakat sekitar adalah sebagai lokasi usaha perikanan air tawar. Usaha perikanan air tawar atau biasa disebut Keramba Jaring Apung (KJA) merupakan salah satu sektor di Kabupaten Purwakarta yang berkontribusi besar dalam meningkatkan kesejahteraan dan membuka peluang kerja untuk masyarakat. Salah satu peluang kerja yang ada adalah sebagai Rumah Tangga Perikanan (RTP) yang terdiri dari pembudidaya ikan, nelayan/penangkapan, pengolah/pedagang, dan buruh perikanan.

Berdasarkan Tabel 1, dapat dilihat bahwa jumlah pembudidaya ikan khususnya budidaya ikan dengan sistem Keramba Jaring Apung (KJA) 
Tabel 1 Perkembangan Rumah Tangga Perikanan (RTP) di Kabupaten Purwakarta tahun 2009 - 2014

\begin{tabular}{|c|c|c|c|c|c|c|c|}
\hline \multirow{2}{*}{ No. } & \multirow{2}{*}{ Lapangan usaha/obyek } & \multicolumn{6}{|c|}{ Jumlah (orang) } \\
\hline & & 2009 & 2010 & 2011 & 2012 & 2013 & 2014 \\
\hline \multirow[t]{6}{*}{ I } & Pembudidaya ikan & & & & & & \\
\hline & 1. Kolam Air Tenang & 4.856 & 5.030 & 6.190 & 6.210 & 6.136 & 6.210 \\
\hline & 2. Kolam Air Deras & 80 & 14 & 20 & - & - & - \\
\hline & 3. Kolam Jaring Apung & 2.115 & 2.115 & 2.115 & 2.135 & 2.115 & 3.405 \\
\hline & 4. Sawah Perikanan & & - & - & - & - & - \\
\hline & Jumlah & 7.051 & 7.159 & 8.325 & 8.345 & 8.251 & 9.615 \\
\hline \multirow[t]{5}{*}{ II } & Nelayan/ Penangkapan & & & & & & \\
\hline & 1. Waduk & 2.445 & 2.267 & 2.267 & 2.267 & 2.198 & 2.070 \\
\hline & 2. Situ/Danau & 290 & 816 & 916 & 941 & 880 & 941 \\
\hline & 3. Sungai & 278 & 263 & 263 & 263 & 210 & 263 \\
\hline & Jumlah & 3.013 & 3.346 & 3.446 & 3.471 & 3.288 & 3.288 \\
\hline \multirow[t]{4}{*}{ III } & Pengolah/Pedagang & & & & & & \\
\hline & 1. Pengolah & 835 & 44 & 44 & 44 & * & $*$ \\
\hline & 2. Pedagang & 50 & 1.050 & 1.050 & 1.050 & $*$ & * \\
\hline & Jumlah & 885 & 1.094 & 1.094 & 1.094 & $*$ & * \\
\hline \multirow[t]{8}{*}{ IV } & Buruh Perikanan & & & & & & \\
\hline & 1. Pembenih & 400 & 455 & * & * & * & * \\
\hline & 2. Kolam Air Deras & 20 & 20 & 10 & 10 & - & - \\
\hline & 3. Sawah Perikanan & - & - & - & - & - & - \\
\hline & 4. KJA & 1.521 & 1.521 & 1.521 & 1.521 & 1.597 & 246 \\
\hline & 5. Kolam Air Tenang & * & * & 1950 & 1950 & 1950 & 1.950 \\
\hline & Jumlah & 1.941 & 1.996 & 3.481 & 3.481 & 3.547 & 2.196 \\
\hline & Jumlah I + II + III + IV & 12.890 & 13.595 & 16.346 & 16.391 & 15.086 & 15.085 \\
\hline
\end{tabular}

Catatan: $*$ data tidak tersedia

Kabupaten Purwakarta pada tahun 2014 paling besar dibandingkan dengan tahun-tahun sebelumnya, yaitu sebesar 3.405 orang. Namun, jumlah buruh perikanan KJA pada tahun 2014 paling sedikit daripada tahun-tahun sebelumnya, yakni sebesar 246 orang. Alasannya karena masyarakat lebih memilih untuk mengelola langsung keramba miliknya.

Lebih rinci, budidaya ikan dengan sistem KJA di Waduk Jatiluhur terbagi atas 5 zona yaitu: Zona
I, Zona II, Zona III, Zona IV dan Zona V (BPMPTSP). Zona-zona ini tersebar di seluruh wilayah perairan Waduk Jatiluhur dengan jumlah maksimal keramba per pemilik usaha sebanyak 20 petak. Namun, masih ada beberapa pembudidaya yang jumlah keramba miliknya lebih dari 20 petak.

Jumlah pembudidaya (petani) ditunjukkan dalam Tabel 2. Jumlah pembudidaya terbanyak berada pada Zona V, yaitu sebesar 9.798 orang. Hal ini dikarenakan kualitas air di wilayah Zona $\mathrm{V}$

Tabel 2 Jumlah petani KJA per zona tahun 2014

\begin{tabular}{ccc}
\hline No. & Zona & Petani KJA (orang) \\
\hline 1. & I & 2.013 \\
2. & II & 1.620 \\
3. & III & 1.346 \\
4. & IV & 1.768 \\
5. & V & 9.798 \\
\hline
\end{tabular}


Tabel 3 Perkembangan produksi perikanan budidaya berdasarkan potensi dan pemanfaatan areal budidaya di Kabupaten Purwakarta tahun 2010 - 2014

\begin{tabular}{cccccr}
\hline No. & Tahun & $\begin{array}{c}\text { Luas wilayah } \\
(\mathrm{Ha})\end{array}$ & $\begin{array}{c}\text { Potensi perikanan } \\
\text { budidaya }(\mathrm{Ha})\end{array}$ & $\begin{array}{c}\text { Pemanfaatan areal } \\
\text { budidaya (Ha) }\end{array}$ & $\begin{array}{r}\text { Produksi hasil } \\
\text { budidaya (ton) }\end{array}$ \\
\hline 1. & 2010 & $90.008,00$ & $1.805,50$ & 135,90 & $71.095,96$ \\
2. & 2011 & $90.008,00$ & $1.805,50$ & 135,90 & $82.571,25$ \\
3. & 2012 & $90.008,00$ & $1.805,50$ & 135,90 & $82.973,25$ \\
4. & 2013 & $90.008,00$ & $1.805,50$ & 105,74 & $58.99,00$ \\
5. & 2014 & $90.008,00$ & $1.805,50$ & 117,60 & $58.265,00$ \\
\hline
\end{tabular}

Catatan: *) Kecamatan

cukup baik dibandingkan zona lainnya. Sesuai dengan hasil pengamatan di lapang, Zona III dan Zona IV telah direlokasi ke zona lainnya. Hal ini sehubungan dengan rencana Perum Jasa Tirta II (PJTII) untuk mengembangkan pariwisata di Waduk Jatiluhur. Kemudian, terdapat pula zona luar yang menurut pihak PJTII tidak termasuk ke dalam zonase keramba di Waduk Jatiluhur. Padahal jumlah KJA terbanyak berada di zona luar. Selain itu, kepemilikan KJA di zona luar kebanyakan adalah milik masyarakat asli Purwakarta.

Berdasarkan tabel di atas tampak bahwa pada tahun 2013, luas areal pemanfaatan untuk budidaya ikan dengan sistem KJA mengalami penurunan daripada tahun 2012. Alasannya, ada peraturan baru yang diterapkan, yaitu satu izin usaha KJA maksimal dengan kepemilikan KJA sebanyak 20 petak. Selain itu, hasil budidaya ikan KJA pun menurun karena terjadi kematian ikan massal pada bulan Januari. Pemicunya ialah adanya arus balik air waduk yang disebabkan oleh cuaca buruk. Kejadian tersebut mengakibatkan kematian ikan kurang lebih 1.000 ton ikan, baik dalam ukuran benih ataupun ukuran konsumsi. Kemudian, kerugian yang dialami pembudidaya diperkirakan mencapai Rp 11,6 milyar. Setelah kejadian tersebut, para pembudidaya tidak langsung memelihara ikan lagi, tetapi menunggu hingga cuaca memungkinkan lagi untuk budidaya.

Pada tahun 2014 luas areal pemanfaatan untuk budidaya ikan dengan sistem KJA mengalami peningkatan. Hal ini terjadi karena masuknya pembudidaya KJA di luar zona ke Zona V. Namun, produksi hasil budidaya ikan pada tahun ini mengalami penurunan sebab para pembudidaya ikan di KJA berhati-hati dalam memelihara ikan untuk menghindari terjadinya arus balik di waduk yang dapat mengakibatkan kematian ikan.

Berdasarkan tabel 4 terlihat bahwa berbeda

Tabel 4 Produksi ikan keramba jaring apung Kabupaten Purwakarta tahun 2009 - 2014

\begin{tabular}{llrrrrrr}
\hline No. & Komoditi & \multicolumn{7}{c}{ Produksi (ton) } \\
\cline { 3 - 7 } & & 2009 & 2010 & 2011 & 2012 & 2013 & 2014 \\
\hline 1. & Mas & $39.565,00$ & $47.452,62$ & $50.375,00$ & $50.022,00$ & $37.195,00$ & $37.970,00$ \\
2. & Nila & $23.673,00$ & $28.392,42$ & $35.480,00$ & $40.089,00$ & $33.785,00$ & $35.160,00$ \\
3. & Patin & $6.616,00$ & $7.934,96$ & $11.545,00$ & $10.870,00$ & $11.200,00$ & $11.155,00$ \\
4. & Bawal & $4.043,00$ & $4.849,01$ & $12.715,00$ & $9.100,00$ & $7.765,00$ & $7.880,00$ \\
& Total & $73.897,00$ & $88.629,00$ & $110.115,00$ & $110.081,00$ & $89.945,00$ & $92.165,00$ \\
\hline
\end{tabular}

Catatan: KJA berada di 4 wilayah yaitu Kecamatan Sukasari, Sukatani, Tegalwaru, dan Maniis Kecamatan Maniis merupakan bagian dari Waduk Cirata 
dengan tahun 2010, pada tahun 2011 terjadi kenaikan produksi ikan KJA karena pasokan benih yang memadai, cuaca yang relatif mendukung usaha budidaya ikan dengan sistem KJA, dan wabah penyakit yang menyerang ikan relatif tidak ada. Kemudian, berbeda dengan tahun 2011 yang mengalami peningkatan, pada 2012 produksi ikan KJA mengalami penurunan sebesar 0,03\%. Alasannya karena para pembudidaya mengurangi penanaman benihnya sehubungan dengan cuaca yang tidak mendukung. Hal yang sama terjadi pada tahun 2013 dan 2014 yang mengalami penurunan dan peningkatan. Jenis ikan yang dibudidayakan di Waduk Jatiluhur mayoritas adalah ikan mas, nila, dan patin/jambal.

\section{METODOLOGI}

Penelitian ini ditentukan secara sengaja (purposive) dengan mempertimbangkan bahwa jumlah KJA di Waduk Jatiluhur telah melebihi daya dukung ekologi waduk dan sebagai bendungan terbesar di Indonesia. Pengambilan data dilakukan pada Bulan Maret-April 2016. Jenis data yang digunakan adalah data primer dan data sekunder.

Dalam penelitian ini, peneliti menggunakan teknik pengambilan sampel non-probability sampling yaitu teknik sampling yang tidak memberikan kesempatan (peluang) pada setiap anggota populasi untuk dijadikan anggota sampel (Riduwan, 2011). Kemudian, teknik sampling yang diterapkan adalah snowball sampling. Kriteria pemilihan responden adalah seluruh pihak yang terlibat dalam pengelolaan KJA dan Waduk Jatiluhur dengan jumlah responden sebanyak 56. Analisis data yang digunakan dalam penelitian ini adalah analisis kualitatif dan analisis kuantitatif.
Perhitungan daya dukung waduk menghasilkan jumlah total ikan maksimum yang dapat dibudidayakan. Selanjutnya melalui total ikan maksimum yang dapat dibudidayakan tersebut dapat digunakan untuk menentukan jumlah KJA optimal.

Penghitungan daya dukung waduk berkaitan dengan budidaya KJA dapat dilakukan dengan beberapa pendekatan yang berbeda, salah satunya adalah dengan metode Beveridge. Daya dukung waduk dapat dihitung berdasarkan kandungan posfat dalam air. Langkah perhitungan daya dukung waduk dengan Metode Beveridge:

$\mathrm{L}_{\text {fish }}=\Delta \mathrm{Pxz \times \varrho} / 1-\mathrm{R}_{\text {fish }}$

$\Delta[\mathrm{P}]_{\mathrm{d}}=[\mathrm{P}]_{\mathrm{STD}}-[\mathrm{P}] \mathrm{i}-[\mathrm{P}]_{\mathrm{DAS}}$

$\mathrm{R}_{\text {fish }}=\mathrm{x}+(1-\mathrm{x}) \mathrm{R}$

$\mathrm{R}=1 /\left(1+0,5 e^{0,5}\right)$ (Beveridge, 1996 dalam Widyastuti et al., 2009)

Total beban Pyang dibolehkan $=\mathrm{L}_{\text {fish }} \times \mathrm{A}$

$\mathrm{P}$ ton pelet untuk tumbuh $=\mathrm{P}$ pelet per tahun $\mathrm{x}$ konversi pelet

Beban P KJA intensif $=\mathrm{P}$ ton pelet $-\mathrm{P}$ ton ikan nila

Daya dukung KJA intensif : jumlah ton ikan yang boleh diproduksi per tahun $=$ total beban $\mathrm{P}$ yang dibolehkan / beban P KJA intensif

Produksi ikan total $=$ produksi ikan nila rata-rata $\mathrm{x}$ jumlah KJA

Keterangan:

$L_{\hat{f i s h}}=$ Jumlah $\mathrm{P}$ total yang dihasilkan oleh aktivitas KJA ( $\left.\mathrm{g} / \mathrm{m}^{3} / \mathrm{thn}\right)$

$\Delta \mathrm{P}=$ Selisih antara $\mathrm{P}$ total yang dapat diterima lingkungan dengan total $P$ yang terukur

$\mathrm{R}_{\text {fish }}=$ Proporsi $\mathrm{P}$ yang larut ke dalam sedimen, dengan rumus:

$\mathrm{x}=$ Proporsi bersih total $\mathrm{P}$ yang secara permanen masuk ke dasar (50\%)

$\mathrm{R}=$ Total $\mathrm{P}$ yang hilang ke sedimen

$\varrho \quad=$ Laju pembilasan air 


\section{ANALISIS DAN ALTERNATIF SOLUSI PENANGANAN}

Komponen-komponen untuk perhitungan daya dukung lingkungan adalah sebagai berikut:

- $\operatorname{Luas}$ waduk $(\mathrm{A})=83.000$ ha atau 83.000.000 $\mathrm{m}^{2}$

- $\operatorname{Volume}(\mathrm{V})=2,443$ miliar $\mathrm{m}^{3}$

- Rataan kedalaman waduk (z)

$=$ luas $(\mathrm{A}) / \operatorname{volume}(\mathrm{V})$

$=37 \mathrm{~m}$

- Waktu pembilasan (flushing time) (@) = 1,50/tahun (Machbub, 2010)

- $[\mathrm{P}]_{\text {STD }}$ yaitu syarat kadar P-total maksimal sesuai baku mutu air atau kelas air $=100 \mathrm{mg} / \mathrm{m}^{3}$ (Machbub, 2010)

- $\mathrm{P}$ sesaat (steady state) $[\mathrm{P}]_{\mathrm{i}}=123 \mathrm{mg} / \mathrm{m}^{3}$ (Machbub, 2010)

- $[\mathrm{P}]_{\mathrm{DAS}}$ yaitu alokasi beban P-total dari DAS dan perairan danau selain budidaya ikan $=50$ $\mathrm{mg} / \mathrm{m}^{3}$ (Machbub, 2010)

- Kandungan P pakan (pelet) dari hasil uji proksimat $=1,27 \%$ maka 1 ton pelet $=12,70$ $\operatorname{kg} \mathrm{P}$ (Widyastuti et al., 2009)

- Persentase kebutuhan P dari pakan pada ikan nila $=0,9 \%$ maka 1 ton ikan $=9 \mathrm{~kg} \mathrm{P}$ (Beveridge, 1996 dalam Widyastuti et al, 2009)

- Rasio konversi pakan (RKP) = 1:2 (Widyastuti et al., 2009)

Menurut Effendi (2004), "Rasio konversi pakan adalah suatu ukuran yang menyatakan rasio jumlah pakan yang dibutuhkan untuk menghasilkan $1 \mathrm{~kg}$ daging ikan kultur". Lebih lanjut, Effendi (2004) menjelaskan jika nilai FCR $=2$ maka pengertiannya adalah untuk memproduksi $1 \mathrm{~kg}$ daging ikan dalam sistem akuakultur maka dibutuhkan $2 \mathrm{~kg}$ pakan. Semakin besar nilai FCR maka semakin banyak pula $\mathrm{kg}$ pakan yang dibutuhkan dalam menghasilkan $1 \mathrm{~kg}$ daging ikan kultur. Hal ini menunjukkan bahwa semakin kecil nilai FCR maka usahanya semakin efisien. Perhitungan rasio konversi pakan adalah berat total pakan yang diberikan hingga ikan panen dibagi dengan berat ikan ketika panen.

- Proporsi P padatan yang permanen hilang ke $\operatorname{sedimen}(\mathrm{x})=0,5$

Perhitungan:

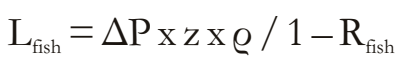

$\Delta[\mathrm{P}]_{\mathrm{d}}$ (alokasi beban P-total budidaya ikan)

$$
\begin{aligned}
& =[\mathrm{P}]_{\mathrm{STD}}-[\mathrm{P}]_{\mathrm{i}}-[\mathrm{P}]_{\mathrm{DAS}} \\
& =[(100-123-50)] \mathrm{mg} / \mathrm{m}^{3} \\
& =[-73] \text { atau } 73 \mathrm{mg} / \mathrm{m}^{3}
\end{aligned}
$$

$\mathrm{R}_{\text {fish }}$ (fraksi dari $\mathrm{L}_{\text {fish }}$ yang tertahan di sedimen $)=\mathrm{x}+$ $(1-\mathrm{x})$ R. R (proporsi total $\mathrm{P}$ yang tertahan di sedimen) $=1 /\left(1+0,5 \varrho^{0,5}\right.$ (Beveridge, 1996 dalam Widyastuti et al., 2009)

$$
\begin{aligned}
& =1 /\left(1+0,5 \times 1,50^{0,5}\right) \\
& =0,620204 \\
\mathrm{R}_{\text {fish }} & =\mathrm{x}+(1-\mathrm{x}) \mathrm{R} \\
& =0,5+(1-0,5) 0,620204 \\
& =0,8101 \\
\mathrm{~L}_{\text {fish }} & =\Delta \mathrm{P} \times \mathrm{z} \times \varrho / 1-\mathrm{R}_{\text {fish }} \\
& =73 \times 37 \times 1,50 /(1-0,8101) \\
& =21334,9 \mathrm{mg} / \mathrm{m}^{2} / \text { tahun } \\
& =2,13349 \mathrm{~g} / \mathrm{m}^{2} / \text { tahun }
\end{aligned}
$$

Total beban P yang diperbolehkan

$=$ Lfish $\mathrm{x}$ A

$=2,13349 \mathrm{~m}^{2} \times 83.000 .000 \mathrm{~m}^{2}$

$=177.079 .670 \mathrm{~g} /$ tahun

$\mathrm{P}$ ton pelet untuk tumbuh

$=\mathrm{P}$ pelet per tahun $\mathrm{x}$ konversi pelet

$=12,7 \times 2$

$=25,4 \mathrm{~kg}$

Beban P KJA intensif

$=\mathrm{P}$ ton pelet untuk tumbuh $-\mathrm{P}$ ton ikan nila untuk tumbuh

$=25,4-9$ 


$$
=16,4 \mathrm{~kg} / \text { tahun atau } 16.400 \mathrm{~g} / \text { tahun }
$$

Daya dukung KJA intensif : jumlah ton ikan yang boleh diproduksi/tahun

$$
\begin{aligned}
= & \text { total beban P yang diperbolehkan / } \\
& \text { beban P KJA intensif } \\
= & 177.079 .670 / 16.400 \\
= & 10.798 \text { ton }
\end{aligned}
$$

Jumlah unit KJA intensif di Waduk Jatiluhur berdasarkan Laporan Tahunan Perum Jasa Tirta II tahun 2014 sebanyak 23.000 KJA. Jumlah KJA ini diambil dengan asumsi bahwa belum dilakukannya penertiban KJA yang sudah tidak beroperasi, ditinggal pemilik, dan sudah tidak layak pakai.

Produksi ikan rata-rata tiap KJA adalah 1,5 ton/panen maka produksi ikan total

$=1,5$ ton $\mathrm{x} 23.000$

$=34.500 \mathrm{ton} /$ panen atau $69.000 \mathrm{ton} /$ tahun dengan asumsi pembudidaya ikan melakukan 2 kali panen selama setahun

Berdasarkan hasil perhitungan tersebut dapat disimpulkan bahwa terdapat kelebihan jumlah produksi ikan di Waduk Jatiluhur dengan jumlah produksi ikan yang diperbolehkan, yaitu sebesar $(69.000$ ton -10.798 ton $)=58.202$ ton $/$ tahun atau 29.101 ton/panen dengan asumsi panen terjadi sebanyak dua kali setahun. Berdasarkan hasil perhitungan tersebut, jumlah KJA optimal di Waduk Jatiluhur adalah 19.401 petak KJA.

Pengelolaan dan pemanfaatan Waduk Jatiluhur terkait dengan aktivitas usaha KJA membutuhkan peraturan-peraturan yang jelas sehingga dalam pelaksanaannya tidak akan memberikan dampak negatif terhadap wilayah perairan waduk. Peraturan-peraturan yang berlaku dapat bersifat formal maupun informal. Peraturan yang bersifat formal seperti Undang-Undang (UU), Peraturan menteri (Permen), Keputusan menteri (Kepmen), Peraturan daerah (Perda) Provinsi Jawa Barat, keputusan gubernur Jawa Barat, dan Peraturan daerah (Perda) Kabupaten Purwakarta. Sedangkan untuk peraturan yang bersifat informal seperti kesepatakan antar masyarakat yang berkaitan dengan KJA Waduk Jatiluhur. Kemudian, peraturan tersebut dapat berasal dari lembaga pemerintahan maupun lembaga nonpemerintahan seperti kesepakatan dari masyarakat.

Peraturan Daerah Provinsi Jawa Barat dan Peraturan Daerah Kabupaten Purwakarta terkait usaha perikanan memiliki perbedaan dalam konten/isi aturannya. Perbandingan kedua aturan dapat dilihat pada Tabel 5.

Analisis persepsi stakeholder Waduk Jatiluhur akan dilakukan untuk melihat persepsi dari masing-masing pihak dalam pengelolaan Waduk Jatiluhur yang berhubungan dengan KJA. Budidaya ikan dengan sistem KJA adalah salah satu kegiatan ekonomi yang berpotensi menurunkan kualitas lingkungan perairan waduk (Purnomo, 2013). Kandungan pakan ikan, kotoran ikan, dan sampah buangan dari aktivitas KJA adalah limbah bagi Waduk Jatiluhur jika tidak dikelola dengan baik.

Berdasarkan hasil identifikasi persepsi pemerintah dan private pada Tabel 13, diketahui bahwa sebesar 57\% kelompok pemerintah dan private mengatakan bahwa kualitas lingkungan Waduk Jatiluhur baik, sebesar 29\% mengatakan buruk, dan sebesar 14\% mengatakan masih cukup baik. Perbedaan persepsi mengenai kualitas lingkungan waduk dari kelompok pemerintah dan private ini khususnya terkait kualitas air Waduk Jatiluhur. Air Waduk Jatiluhur secara umum masih baik untuk pengairan irigasi sesuai dengan SK Gubernur Jawa Barat Nomor 39 Tahun 2000 tentang Peruntukan Air dan Baku Mutu Air pada Sungai Citarum dan Anak-anak Sungainya di Jawa 
Tabel 5 Perbandingan peraturan daerah Provinsi Jawa Barat dan peraturan Daerah Kabupaten Purwakarta

\begin{tabular}{|c|c|c|}
\hline Parameter & $\begin{array}{l}\text { Peraturan Daerah Provinsi Jawa Barat } \\
\text { Nomor } 14 \text { Tahun } 2002 \text { tentang Usaha } \\
\text { Perikanan dan Retribusi Usaha Perikanan }\end{array}$ & $\begin{array}{l}\text { Peraturan Daerah Kabupaten Purwakarta } \\
\text { Nomor } 6 \text { Tahun } 2010 \text { tentang Retribusi } \\
\text { Izin Usaha Perikanan }\end{array}$ \\
\hline $\begin{array}{l}\text { Jenis usaha dan } \\
\text { bentuk perusahaan } \\
\text { perikanan }\end{array}$ & $\begin{array}{l}\text { Usaha perikanan terdiri atas: usaha } \\
\text { penangkapan ikan, usaha pengangkutan } \\
\text { ikan, usaha penangkapan dan } \\
\text { pengangkutan ikan, dan usaha } \\
\text { pembudidayaan ikan . Perusahaan } \\
\text { perikanan dalam bentuk usaha } \\
\text { perseorangan Warga Negara Republik } \\
\text { Indonesia atau badan. }\end{array}$ & $\begin{array}{l}\text { Usaha perikanan terdiri atas usaha } \\
\text { penangkapan ikan dan usaha } \\
\text { pembudidayaan ikan. Perusahaan } \\
\text { perikanan dalam bentuk usaha } \\
\text { perseorangan Warga Negara Republik } \\
\text { Indonesia atau badan. }\end{array}$ \\
\hline Perizinan & $\begin{array}{l}\text { Setiap perusahaan perikanan yang } \\
\text { melakukan usaha perikanan wajib } \\
\text { memiliki IUP dari Gubernur. Setiap unit } \\
\text { keramba jaring apung wajib dilengkapi } \\
\text { SPbI yang diterbitkan oleh Gubernur. } \\
\text { IUP dan kelengkapannya dapat } \\
\text { dipindahtangankan seperti waris, hibah, } \\
\text { dan jual beli. }\end{array}$ & $\begin{array}{l}\text { Orang pribadi atau badan hukum yang } \\
\text { akan memanfaatkan ikan untuk kegiatan } \\
\text { usaha diwajibkan mempunyai IUP yang } \\
\text { ditetapkan oleh Bupati. IUP merupakan } \\
\text { dasar penerbitan sewa lahan oleh } \\
\text { pengelola kawasan perairan. Pengelola } \\
\text { kawasan perairan wajib mengajukan izin } \\
\text { pemanfaatan ruang yang akan digunakan } \\
\text { untuk area usaha perikanan kepada } \\
\text { Bupati. }\end{array}$ \\
\hline
\end{tabular}

Retribusi Perhitungan retribusi pengusahaan perikanan untuk keramba jaring apung didasarkan atas jumlah petak per unit keramba jari ng apung. Seluruh hasil pungutan retribusi disetor secara bruto ke Kas Daerah Provinsi Jawa Barat.

Obyek retribusi IUP meliputi usaha pembudidayaan dengan keramba jaring apung yang lebih dari 4 petak. Besaran tarif retribusi IUP sebesar Rp 500. 000 untuk u saha keramba jaring apung. Penerimaan dari retribusi digunakan untuk membiayai kegiatan yang berkaitan dengan pelayanan perizinan yang dialokasikan pada APBD setiap tahun anggaran yang berkenaan.

\section{Pembinaan, pengawasan, dan pengendalian}

\section{Pembinaan, pengawasan, dan} pengendalian atas pelaksanaan Peraturan Daerah ini dilakukan oleh Gubernur yang dalam pelaksanaannya dilakukan oleh Dinas berkoordinasi dengan instansi terkait.
Pengawasan atas Peraturan Daerah ini secara teknis dan operasional dikoordinasikan oleh Satuan Kerja Perangkat Daerah (SKPD). Untuk kepentingan pengawssan, setiap instansi pemerintah atau swasta wajib memberikan kesempatan kepada petugas untuk mengadakan pemeriksaan serta memperlihatkan/memberikan data yang diperlukan. terutang sanksi administrasi berupa bunga kurang membayar dikenakan sanksi sebesar $2 \%$ (dua persen) setiap bulan dan administratif berupa bunga sebesar $2 \%$ ditagih dengan menggunakan Surat Tagihan Retribusi Daerah (STRD). (dua persen) setiap bulan dari retribusi yang terutang dan ditagih menggunakan STRD. Setiap orang atau badan usaha yang tidak memperpanjang IUP akan dikenakan sanksi pencabutan IUP yang dimiliki. 
Tabel 5 Lanjutan

\begin{tabular}{lll}
\hline Parameter & Peraturan Daerah Provinsi Jawa Barat & Peraturan Daerah Kabupaten Purwakarta \\
& Nomor 14 Tahun 2002 tentang Usaha & Nomor 6 Tahun 2010 tentang Retribusi \\
& Perikanan dan Retribusi Usaha Perikanan & Izin Usaha Perikanan \\
\hline Ketentuan Pidana & Perusahaan perikanan yang tidak memiliki & Setiap orang atau badan usaha yang tidak \\
& IUP, SPbI, atau pergantian kepemilikan & memiliki IUP, tidak memperpanjang masa \\
& keramba jaring apung yang tidak disertai & berlaku IUP, atau tidak membayar \\
& kelengkapan surat -surat diancam pidana & retribusi IUP maka diancam pidana \\
& kurungan selama -lamanya 3 (tiga) bulan & kurungan selama-lamanya 3 (tiga) bulan \\
& atau denda sebanyak-banyaknya Rp 5.000. & atau denda setinggi-tingginya 3 (tiga) kali \\
& 000 (lima juta rupiah). & jumlah retribusi terutang yang tidak atau \\
& & kurang bayar. Denda merupakan \\
& penerimaan negara. \\
\hline
\end{tabular}

Tabel 6 Sebaran persepsi pemerintah dan private terhadap kondisi lingkungan Waduk Jatiluhur dan keberadaan KJA

\begin{tabular}{|c|c|c|c|}
\hline & Kondisi Lingkungan Waduk Jatiluhur dan & & \\
\hline & Keberadaan KJA & Jumlah (orang) & Persentase $(\%)$ \\
\hline & a. Keberadaan Waduk Jatiluhur & & \\
\hline 1. & Sangat tidak penting & 0 & 0 \\
\hline 2. & Tidak penting & 0 & 0 \\
\hline 3. & Cukup penting & 0 & 0 \\
\hline 4. & Penting & 2 & 29 \\
\hline 5. & Sangat penting & 5 & 71 \\
\hline & b. Kualitas Lingkungan Waduk & & \\
\hline 1. & Sangat buruk & 0 & 0 \\
\hline 2. & Buruk & 2 & 29 \\
\hline 3. & Cukup baik & 1 & 14 \\
\hline 4. & Baik & 4 & 57 \\
\hline 5. & Sangat baik & 0 & 0 \\
\hline & c. Tingkat Pencemaran & & \\
\hline 1. & Sangat rendah & 0 & 0 \\
\hline 2. & Rendah & 0 & 0 \\
\hline 3. & Sedang & 2 & 29 \\
\hline 4. & Tinggi & 4 & 57 \\
\hline 5. & Sangat tinggi & 1 & 14 \\
\hline & d. Kelestarian Waduk Jatiluhur & & \\
\hline 1. & Sangat tidak penting & 0 & 0 \\
\hline 2. & Tidak penting & 0 & 0 \\
\hline 3. & Cukup penting & 0 & 0 \\
\hline 4. & Penting & 0 & 0 \\
\hline 5. & Sangat penting & 7 & 100 \\
\hline & e. Daya Dukung Waduk & & \\
\hline 1. & Sangat buruk & 0 & 0 \\
\hline 2. & Buruk & 1 & 14 \\
\hline 3. & Cukup baik & 2 & 29 \\
\hline 4. & Baik & 4 & 57 \\
\hline 5. & Sangat baik & 0 & 0 \\
\hline & f. Pengelolaan KJA & & \\
\hline 1. & Sangat buruk & 0 & 0 \\
\hline 2. & Buruk & 1 & 14 \\
\hline
\end{tabular}


Tabel 6 Lanjutan

\begin{tabular}{llcc}
\hline & Kondisi Lingkungan Waduk Jatiluhur dan & \multicolumn{2}{c}{ Sebaran Persepsi } \\
\cline { 3 - 4 } Keberadaan KJA & \multicolumn{1}{c}{ Jumlah (orang) } & Persentase $(\%)$ \\
\hline 3. & Cukup baik & 2 & 29 \\
4. & Baik & 3 & 43 \\
5. & Sangat baik & 1 & 14 \\
\hline & g. Jumlah KJA & & 0 \\
1. & Sangat sedikit & 0 & 0 \\
2. & Sedikit & 0 & 0 \\
3. & Sedang & 0 & 29 \\
4. & Banyak & 2 & 71 \\
5. & Sangat banyak & 5 & 0 \\
& h. Pembatasan Jumlah KJA & & 0 \\
1. & Sangat tidak perlu & 0 & 0 \\
2. & Tidak perlu & 0 & 29 \\
3. & Cukup perlu & 0 & 71 \\
4. & Perlu & 2 & \\
5. & Sangat perlu & 5 & \\
\hline
\end{tabular}

Sumber: Fitri, (2016)

Barat, namun produksi ikan dari usaha budidaya KJA mengalami penurunan setiap tahunnya.

Sebanyak 57\% kelompok pemerintah dan private mengatakan bahwa tingkat pencemaran yang terjadi di Waduk Jatiluhur tinggi, sebanyak $29 \%$ mengatakan sedang, dan sebanyak 14\% mengatakan sangat tinggi. Hal ini dilihat dari tingginya pertumbuhan jumlah KJA di Waduk Jatiluhur yang telah melebihi kapasitas waduk. Peningkatan jumlah petakan KJA akan meningkatkan buangan limbah organik atau sisa metabolisme ikan. Hal ini akan memengaruhi

Tabel 7 Sebaran persepsi pemerintah dan private terhadap peluang bekerja dan pendapatan dari usaha $\mathrm{KJA}$

\begin{tabular}{|c|c|c|}
\hline \multirow[t]{2}{*}{ Peluang Bekerja dan Pendapatan dari Usaha KJA } & \multicolumn{2}{|c|}{ Sebaran Persepsi } \\
\hline & Jumlah (orang) & Persentase $(\%)$ \\
\hline a. Peluang bekerja dan berusaha & & \\
\hline Sangat sedikit & 0 & 0 \\
\hline Sedikit & 0 & 0 \\
\hline Sedang & 0 & 0 \\
\hline Banyak & 2 & 29 \\
\hline Sangat banyak & 5 & 71 \\
\hline b. Pendapatan Asli Daerah (PAD) & & \\
\hline Sangat rendah & 2 & 29 \\
\hline Rendah & 0 & 0 \\
\hline Sedang & 5 & 71 \\
\hline Tinggi & 0 & 0 \\
\hline Sangat tinggi & 0 & 0 \\
\hline c. Kebutuhan konsumsi ikan & & \\
\hline Sangat tidak terpenuhi & 0 & 0 \\
\hline Tidak terpenuhi & 0 & 0 \\
\hline Cukup terpenuhi & 6 & 86 \\
\hline Terpenuhi & 1 & 14 \\
\hline Sangat terpenuhi & 0 & 0 \\
\hline
\end{tabular}


Tabel 8 Sebaran persepsi pemerintah dan private terhadap kejelasan dan pelaksanaan aturan terkait KJA

\begin{tabular}{|c|c|c|c|}
\hline \multirow{2}{*}{\multicolumn{2}{|c|}{ Kejelasan dan Pelaksanaan Aturan terkait KJA }} & \multicolumn{2}{|c|}{ Sebaran Persepsi } \\
\hline & & Jumlah (orang) & Persentase $(\%)$ \\
\hline & a. Kejelasan aturan pengelolaan waduk & & \\
\hline 1. & Sangat tidak jelas & 0 & 0 \\
\hline 2. & Tidak jelas & 2 & 29 \\
\hline 3. & Cukup jelas & 2 & 29 \\
\hline 4. & Jelas & 1 & 14 \\
\hline \multirow[t]{2}{*}{5.} & Sangat jelas & 2 & 29 \\
\hline & b. Kejelasan aturan usaha KJA & & \\
\hline 1. & Sangat tidak jelas & 0 & 0 \\
\hline 2. & Tidak jelas & 1 & 14 \\
\hline 3. & Cukup jelas & 2 & 29 \\
\hline 4. & Jelas & 2 & 29 \\
\hline & Sangat jelas & 2 & 29 \\
\hline & c. Proses perizinan usaha KJA & & \\
\hline 1. & Sangat tidak jelas & 0 & 0 \\
\hline 2. & Tidak jelas & 2 & 29 \\
\hline 3. & Cukup jelas & 1 & 14 \\
\hline 4. & Jelas & 3 & 43 \\
\hline & Sangat jelas & 1 & 14 \\
\hline & d. Upaya perbaikan wilayah & & \\
\hline 1. & Sangat tidak perlu & 0 & 0 \\
\hline 2. & Tidak perlu & 0 & 0 \\
\hline & Cukup perlu & 0 & 0 \\
\hline & Perlu & 1 & 14 \\
\hline & Sangat perlu & 6 & 86 \\
\hline
\end{tabular}

Sumber: Fitri, (2016)

kualitas air waduk.

Berdasarkan hasil identifikasi dari Tabel 7 menunjukkan bahwa sebesar 71\% kelompok pemerintah dan private mengatakan peluang bekerja dan berusaha bagi masyarakat sekitar waduk sangat banyak dan sebesar 29\% mengatakan banyak. Adanya kegiatan KJA mampu menyerap tenaga kerja baik lokal maupun pendatang sehingga mengurangi tingkat pengangguran di Kabupaten Purwakarta. Berdasarkan hasil wawancara dengan responden, diketahui sebesar 71\% mengatakan bahwa Pendapatan Asli Daerah (PAD) terkait usaha KJA sedang dan 29\% mengatakan sangat rendah. Hal ini dilihat dari total pajak retribusi yang diterima pemerintah yaitu sebesar Rp 500.000,- per 3 tahun per 20 petak. Pembudidaya KJA yang diwajibkan membayar adalah pengusaha yang memiliki petakan KJA lebih dari 4 petak karena sesuai dengan Perda Bupati Purwakarta Nomor 6 Tahun 2010.

Berdasarkan hasil identifikasi Tabel 8 menunjukkan bahwa sebesar 29\% kelompok pemerintah dan private mengatakan aturan terkait pengelolaan waduk sangat jelas dan cukup jelas, dan sebesar 14\% mengatakan jelas. Namun sebesar 29\% mengatakan tidak jelas. Hal ini dikarenakan semua aturan telah disusun sesuai dengan kewenangan Perum Jasa Tirta II sebagai pengelola waduk.

Sebesar 29\% pemerintah dan private mengatakan bahwa aturan mengenai usaha KJA cukup jelas, jelas, dan sangat jelas. Sedangkan 14\% lagi mengatakan tidak jelas. Hal ini dikarenakan aturan tersebut telah disusun dalam Peraturan Daerah Kabupaten Purwakarta Nomor 6 Tahun 
2010 tentang Retribusi Izin Usaha Perikanan. Kemudian, sebesar 43\% kelompok pemerintah dan private mengatakan bahwa proses perizinan usaha KJA sudah jelas dan dipahami oleh masyarakat. Sebesar 29\% mengatakan tidak jelas, dan masing-masing sebesar 14\% mengatakan cukup jelas dan sangat jelas. Hal ini dikarenakan adanya kegiatan sosialisasi yang rutin dilakukan oleh pemerintah kepada kelompok pembudidaya ikan terkait pengelolaan usaha KJA yang sesuai dengan aturan dan berbasiskan lingkungan..

\section{REFERENSI}

[BPMPTSP] Badan Penanaman Modal dan Pelayanan Terpadu Satu Pintu. No date. Surat Izin Usaha Perikanan. [diunduh: 2016 Maret 17]. Tersedia pada: http://bpmptsp. purwakartakab.go.id/index.php/perizinan /jenis-perizinan/lkt3/siupkja-per.

Effendi, I. 2004. Pengantar Akuakultur. Jakarta (ID): Penebar Swadaya.
Machbub, B. 2010. Model Perhitungan Daya Tampung Beban Pencemaran Air Danau atau Waduk. Jurnal Sumber Daya Air. Vol. 6(2) 2010. pp: 103-204.

Nasution, Z. 2005. Analisis Kelembagaan dalam Pengelolaan Lingkungan Perairan Waduk (Studi Kasus di Perairan Waduk Jatiluhur, Jawa Barat). 5(1).

Purnomo, K., Andri W., Endi, S.K. 2013. Daya Dukung dan Potensi Produksi Ikan Waduk Sempor di Kabupaten Kebumen, Provinsi Jawa Tengah. Jurnal Penelitian Perikanan Indonesia 19(4) 2013 pp: 203-212.

Pemerintah Daerah Jawa Barat. 2000. SK Gubernur Jawa Barat Nomor 39 Tahun 2000 tentang Peruntukan Air dan Baku Mutu Air pada Sungai Citarum dan Anakanak Sungainya di Jawa Barat.

Widyastuti, E., Piranti, A.S., Rahayu, R.U.S. 2009. Monitoring Status Daya Dukung Perairan Waduk Wadaslintang bagi Budidaya Keramba Jaring Apung. Jurnal Manusia dan Lingkungan. Vol. 16(3) 2009.pp: 133-140 